\section{Central venous pressure and peripheral venous pressure, however correlated are still both in the gray-area}

Sir,

In their prospective observational study Kumar et al. demonstrated an acceptable correlation between central venous pressure (CVP) and peripheral venous pressure (PVP), especially when CVP $>10 \mathrm{~cm} \mathrm{H}_{2} \mathrm{O}^{[1]}$ They proposed to use PVP measurement to guide fluid therapy in a wide variety of critically ill patients. Whereas being of very high interest for clinicians, we would like to underline some drawbacks that may prevent the efficient use of PVP.

First, several studies have shown that CVP was not a reliable indicator of cardiac preload and a review of literature concluded in 2008 that CVP should not be used to guide fluid management. ${ }^{[2]}$ This might be too restrictive because the physiology tells us that CVP reflects the diastolic pressure of the right ventricle. Very low values of CVP $<7 \mathrm{~mm} \mathrm{H}_{2} \mathrm{O}$ predicted a positive response to fluid loading. ${ }^{[3]}$ However, for values between 5 and $15 \mathrm{~mm}$ $\mathrm{Hg}$ the gray-zone approach should be applied, so as to increase the utility of diagnostic measures. ${ }^{[4]}$ This means that doctors should be aware that their measurements may be inconclusive in approximately $25 \%$ of patients for prediction of fluid responsiveness.

Second, as underlined by Peyton and Chong, a percentage error of $30 \%$ or less for cardiac output monitoring is unrealistic. ${ }^{[5]}$ The authors concluded that a percentage error in agreement with thermodilution of $\pm 45 \%$ represented a more realistic expectation of achievable precision in clinical practice.

As regards as the golden hour concept in sepsis management, the methods presented by Kumar et al. have the advantage of being easy to use. In this view, an end-point clinical survey using PVP in early treatment of sepsis would be very interesting.

Financial support and sponsorship Institutional grant from Begin Military Hospital.

\section{Conflicts of interest}

There are no conflicts of interest. 
Matthieu Pissot, Alexandre Salvadori, Kevin Kearns, Clement Dubost

Department of Anaesthesiology and Intensive Care Medicine, Begin Military Hospital, 69, Avenue de Paris, 94163 Saint-Mandé, France

Correspondence:

Dr. Clement Dubost,

Department of Anaesthesiology and Intensive Care Medicine, Begin Military Hospital, 69, Avenue de Paris, 94163 Saint-Mandé, France. E-mail: clement.dubost@ hotmail.fr

\section{References}

1. Kumar D, Ahmed SM, Ali S, Ray U, Varshney A, Doley K. Correlation between central venous pressure and peripheral venous pressure with passive leg raise in patients on mechanical ventilation. Indian J Crit Care Med 2015;19:648-54.

2. Marik PE, Baram M, Vahid B. Does central venous pressure predict fluid responsiveness? A systematic review of the literature and the tale of seven mares. Chest 2008;134:172-8.

3. Dellinger RP, Levy MM, Rhodes A, Annane D, Gerlach H, Opal SM, et al. Surviving sepsis campaign: International guidelines for management of severe sepsis and septic shock: 2012. Crit Care Med 2013;41:580-637.

4. Cannesson M, Le Manach Y, Hofer CK, Goarin JP, Lehot JJ, Vallet B, et al. Assessing the diagnostic accuracy of pulse pressure variations for the prediction of fluid responsiveness: A "gray zone" approach. Anesthesiology 2011;115:231-41.

5. Peyton PJ, Chong SW. Minimally invasive measurement of cardiac output during surgery and critical care: A meta-analysis of accuracy and precision. Anesthesiology 2010;113:1220-35.

This is an open access article distributed under the terms of the Creative Commons Attribution-NonCommercial-ShareAlike 3.0 License, which allows others to remix, tweak, and build upon the work non-commercially, as long as the author is credited and the new creations are licensed under the identical terms.

\begin{tabular}{|l|l|}
\hline \multicolumn{2}{|c|}{ Access this article online } \\
\hline Quick Response Code: & Website: \\
\hline & www.ijccm.org \\
\cline { 2 - 3 } & Dol: 10.4103/0972-5229.173698 \\
\hline
\end{tabular}

How to cite this article: Pissot M, Salvadori A, Kearns K, Dubost C. Central venous pressure and peripheral venous pressure, however correlated are still both in the grayarea. Indian J Crit Care Med 2016;20:58-9. 